\title{
Implementasi Lingkungan Realitas Maya dengan Menggunakan Cave Automated Virtual Environment (CAVE)
}

\author{
Ahmad Ridwan Fauzi, Imam Kuswardayan, dan Darlis Herumurti \\ Jurusan Teknik Informatika, Fakultas Teknologi Informasi, Institut Teknologi Sepuluh Nopember (ITS) \\ Jl. Arief Rahman Hakim, Surabaya 60111 Indonesia \\ e-mail: imam@if.its.ac.id; kajur_tinformatika@its.ac.id
}

\begin{abstract}
Abstrak-Realitas maya merupakan teknologi yang sedang umum dibicarakan dewasa ini. Untuk menghadirkan sensasi yang semakin nyata terasa, diperlukan suatu perangkat yang mampu menghadirkan lingkungan maya tersebut sehingga dapat terasa sangat nyata dan seolah-olah terjadi bagi penggunanya. Terdapat perangkat CAVE yang telah diterapkan di beberapa negara, akan tetapi perangkat ini belum banyak dijumpai di Indonesia. Selain dapat menghadirkan lingkungan maya, perangkat ini mampu digunakan oleh beberapa orang dalam satu sesi, serta tidak secara langsung mengisolasi lingkungan maya dengan lingkungan nyata. Perangkat CAVE tersusun atas 4 komputer yang masing-masing bertanggung jawab untuk menampilkan gambar pada 4 proyektor yang disusun berbentuk kubus. Hasil pengujian dengan mensimulasikan perangkat ini menggunakan monitor saja menunjukkan hasil yang kurang baik dari segi penilaian tingkat imersif. Namun perangkat ini masih memiliki potensi yang cukup baik apabila diuji dan diterapkan dengan menggunakan komponen yang sesuai. Fungsi lainnya, seperti interaksi pengguna dengan perangkat, rasa pusing yang dialami, serta realisme yang disajikan oleh dua scene yang telah disediakan menunjukkan hasil yang cukup baik.
\end{abstract}

Kata Kunci-CAVE, Unity, Perangkat Realitas Maya, Proyektor, Virtual Reality

\section{PENDAHULUAN}

$\mathrm{P}$ ENERAPAN realitas maya menggunakan perangkat yang sedang terkenal saat ini di pasaran, seperti Oculus Rift, HTC Vive, dan Google Cardboard, tidak dapat digunakan oleh banyak orang dalam satu sesi. Selain itu, penggunaan perangkat ini juga sepenuhnya mengisolasi pengguna dari dunia nyata menuju dunia maya. Hal tersebut memang dapat meningkatkan tingkat imersif yang dimiliki oleh suatu perangkat, akan tetapi berdampak pada rasa pusing yang dialami oleh pengguna. Rasa pusing tersebut timbul akibat adanya ketimpangan yang dialami oleh pengguna pada dunia maya dengan dunia nyata. Perangkat CAVE pada riset kali ini hadir untuk mengatasi masalah tersebut.

Pada umumnya, perangkat ini tersusun atas 4 proyektor. Keempat proyektor tersebut menayangkan sisi pandang depan, kanan, kiri, dan bawah. Proyektor-proyekter tersebut disusun membentuk kubus yang pada akhirnya dapat menampilkan lingkungan maya tanpa harus mengisolasi pengguna dari dunia nyata menuju dunia maya. Untuk menampilkan satu gambar dengan sudut pandang yang berbeda, diperlukan 4 komputer yang masing-masing dihubungkan dengan satu proyektor.
Apabila telah tersusun membentuk kubus, pengguna dapat berdiri di tengah ruangan dan dapat melihat dunia maya yang telah disajikan untuk perangkat tersebut layaknya perangkat HMD (Head Mounted Display) pada umumnya.

Pada komputer tersebut terdapat aplikasi yang dapat dijalankan agar komputer satu dengan yang lainnya dapat tersinkronisasi menampilkan gambar yang sama dengan sisi pandang yang berbeda. Aplikasi terbagi menjadi dua, yaitu aplikasi untuk komputer server dan aplikasi untuk komputer client. Pada aplikasi ini, terdapat peta yang tersusun oleh model 3 dimensi membentuk sebuah lingkungan, serta kamera untuk menampilkan lingkungan tersebut. Aplikasi pada komputer server bertindak sebagai penyedia interaksi antara pengguna dengan komputer serta penyiar data sedangkan komputer client bertindak sebagai penerima data. Data yang disiarkan dari komputer server ke komputer client adalah data posisi dan rotasi kamera. Ketika data tersebut telah diterima oleh client, maka antar komputer akan saling tersinkronisasi dan masing-masing komputer akan menampilkan gambar yang sama dengan sudut pandang yang berbeda.

Pengujian dilakukan dengan mensimulasikan perangkat ini dengan menggunakan 3 monitor yang disusun membentuk kubus. Satu monitor bertindak sebagai server yang menampilkan sisi pandang depan, sisanya bertindak sebagai client yang menampilkan sisi pandang kanan dan kiri.

\section{TINJAUAN PUSTAKA}

\section{A. CAVE}

CAVE adalah singkatan dari Cave Automated Virtual Environment. CAVE adalah realitas maya berbasis proyeksi yang dikembangkan di Electronic Visualization Laboratory (EVL) terletak di University of Illinois. Teknologi ini pertama kali dipublikasikan pada SIGGRAPH tahun 1992.[1]

Sistem ini sendiri dibangun sebagai solusi atas keterbatasannya realitas maya dengan menggunakan alat HMD (Head Mounted Display), khususnya untuk penerapan saintifik dan teknik. CAVE menggunakan layar yang besar dan tetap. Hal ini mengurangi keterbatasan pengguna dan memungkinkan beberapa orang membagikan pengalaman realitas maya yang sama. Gambar 1 menunjukkan contoh sistem CAVE yang telah diterapkan saat ini.

Keuntungan CAVE sendiri adalah masih terasa imersif 


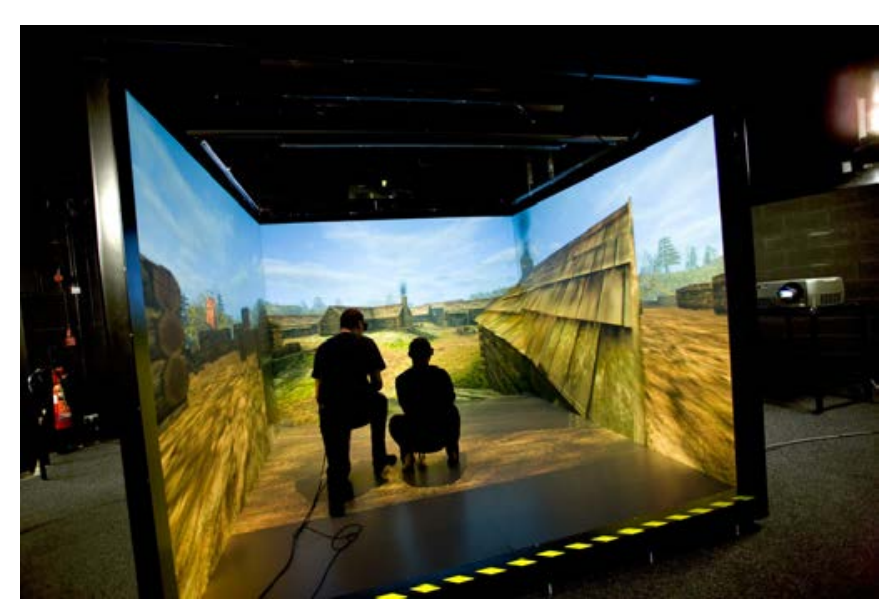

Gambar. 1. Perangkat CAVE yang telah berhasil diterapkan. Perangkat tersebut memiliki 4 sisi pandang, yaitu depan, bawah, kanan, dan kiri.

namun tidak mengisolasi pengguna dari dunia yang sesungguhnya. Seringkali isolasi dari dunia nyata tersebut akan membuat pengguna mudah bosan dan memusingkan. CAVE juga dapat digunakan bagi ilmuwan dan insinyur untuk melakukan eksplorasi data serta melakukan ulasan desain.[2]

CAVE kedua dibangun tahun 1994 di NCSA (National Supercomputing Application).[1] CAVE tersebut digunakan sebagai uji coba untuk mengaplikasikan teknologi baru bagi penerapan saintifik dan teknik. Grup Visualization and Virtual Environment NCSA mengembangkan sistem CAVE yang dibuat khusus untuk membantu peneliti memvisualisasikan datanya dengan lebih baik.[4]

\section{B. Unity3D}

Kakas Unity dapat membangun lingkungan maya yang akan digunakan oleh CAVE. Unity adalah kakas game engine yang biasanya digunakan untuk mengembangkan video game untuk PC, console, perangkat mobile, dan situs. Pada bulan November 2012, lebih dari 1,3 juta pengembang telah menggunakan kakas Unity untuk mengembangkan permainan ke berbagai perangkat yang ada. ${ }^{[5]}$ Tahun 2013, pengembang Unity telah berkembang hingga 2 juta.[3]

Saat ini, Unity telah mengalami beberapa perkembangan sampai versi 5 . Unity 5 menyediakan beberapa pembaruan yang banyak dari perkembangan sebelumnya termasuk pembaruan animasi dan fisik, sistem pencahayaan yang baru, dan penambahan pilihan audio. Selain itu, Unity 5 pun sudah mendukung mesin fisik PhysX versi terbaru dan terdapat beberapa kakas untuk melakukan audio mixing.[7] Unity bukanlah kakas yang paling efisien di antara kakas untuk mengembangkan permainan yang ada di pasar, namun Unity merupakan kakas yang fleksibel dan mendukung banyak perangkat..

Banyaknya forum diskusi dan referensi lain di internet untuk membantu pengembang aplikasi jika mendapat masalah. Asset Store yang merupakan tempat jual beli asset sehingga pengembang tidak perlu susah untuk mendapatkan modul yang diinginkan.

\section{Arsitektur Client-Server}

Arsitektur Client-Server selalu dikaitkan dengan layanan. Pada tiap arsitektur yang diterapkan, sesuai dengan namanya, terdapat client dan server. Client adalah sebuah entitas yang dapat meminta layanan, sedangkan server adalah penyedia layanan. Permintaan layanan adalah tentang "apa” yang dibutuhkan dan selesai atau tidaknya suatu pekerjaan bergantung oleh server. Arsitektur Client-Server yang ideal tidak bergantung akan sistem operasi atau perangkat keras yang digunakan.

Pada arsitektur Client-Server terdapat arsitektur 2-Tier dan 3-Tier. Arsitektur 2-Tier adalah arsitektur yang mana client mengirimkan permintaan pada server dan server secara langsung melayani permintaan client tersebut.[6] Sedangkan arsitektur 3-Tier terdiri dari client, middleware (application server), dan server. Pada arsitektur ini client mengirimkan permintaan kepada server, namun permintaan tersebut terlebih dahulu masuk ke middleware yang nantinya diteruskan secara langsung ke server.

\section{IMPLEMENTASI}

\section{A. Penerapan Aplikasi}

Aplikasi digunakan untuk mensinkronisasikan posisi dan rotasi kamera yang ada di dalam aplikasi antar komputer serta menayangkan scene dan menambahkan interaksi berupa eksplorasi scene bagi pengguna. Masing-masing komputer terhubung dalam satu jaringan LAN. Aplikasi dibedakan menjadi dua, aplikasi server untuk menyiarkan data ke seluruh komputer client, dan aplikasi client untuk menerima data dari komputer server. Komputer server pada kasus ini juga bertindak sebagai penggerak dan pemutar kamera dalam aplikasi, sedangkan komputer client hanya digunakan untuk menerima data posisi dan rotasi kamera serta menampilkan gambar dengan sisi pandang kamera yang berbeda.

Aplikasi server akan dihubungkan dengan joypad sebagai alat yang akan digunakan untuk berinteraksi. Pengguna hanya cukup menjalankan aplikasi yang telah dibangun dan menghubungkan aplikasi yang dikhususkan untuk client dengan aplikasi untuk server.

Eksplorasi yang dimaksud pada kali ini adalah dengan melakukan pergerakan di dalam aplikasi. Scene yang telah disediakan cukup luas bagi pengguna agar dapat melakukan eksplorasi dengan cukup puas. Pengguna berinteraksi dengan joypad agar dapat maju ke arah yang diinginkan. Rotasi kamera akan diatur dengan menggunakan ponsel yang memiliki gyrosensor. Ponsel ini akan ditaruh di atas kepala pengguna sehingga apabila kepala pengguna bergerak, maka kamera yang ada di dalam aplikasi akan berputar. Apabila seluruh komponen dalam aplikasi ini sudah tersinkronisasi dengan baik, maka sistem CAVE berjalan sebagaimana mestinya dan lingkungan realitas maya dapat dihadirkan pada sistem ini dan digunakan oleh beberapa pengguna dalam satu sesi, tidak seperti perangkat realitas maya lain pada umumnya. Scene yang digunakan pada aplikasi ini dapat dilihat pada Gambar 2 dan Gambar 3. 


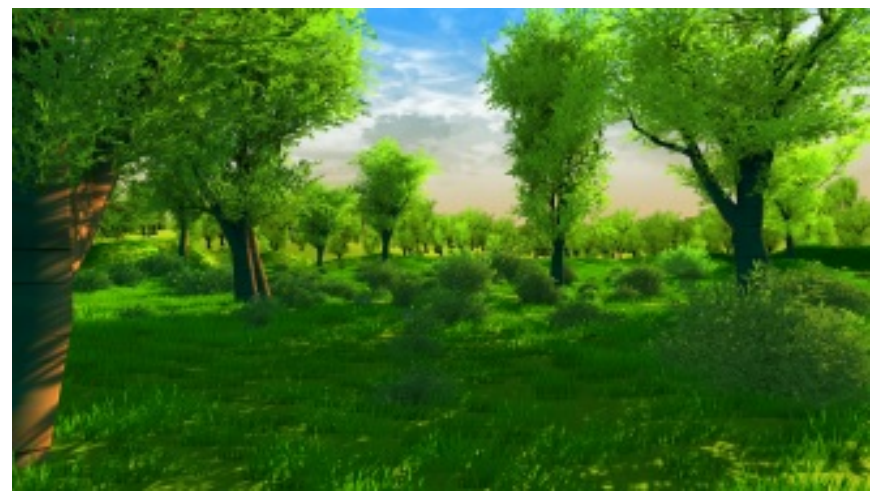

Gambar 2. Scene pemandangan alam yang tersusun atas pepohonan dan ladang rumput

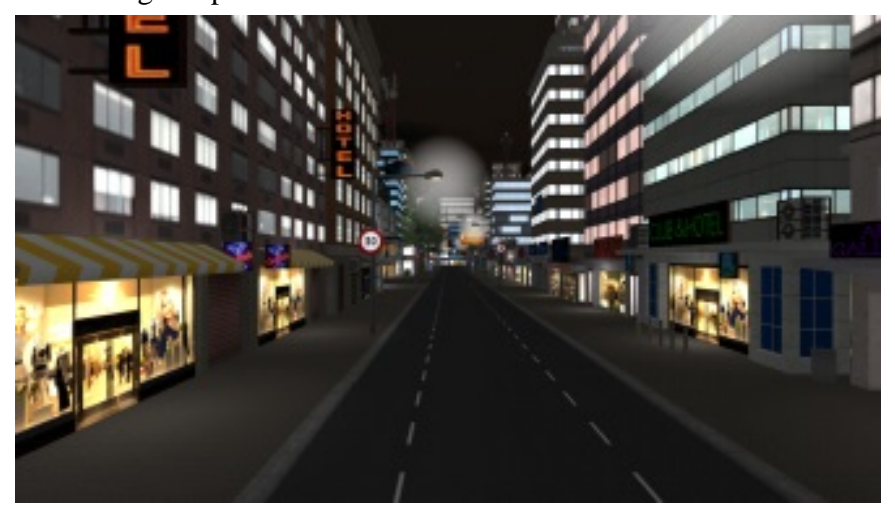

Gambar 3. Scene perkotaan yang tersusun atas bangunan

\section{B. Penerapan Perangkat}

Pada riset kali ini, perangkat disimulasikan dengan menggunakan 3 monitor. Masing-masing monitor terhubung pada satu komputer. Satu komputer yang bertindak sebagai server ditempatkan di tengah untuk menayangkan sisi pandang depan sedangkan dua komputer lainnya yang bertindak sebagai client ditempatkan di sebelah kanan dan kiri server dan dimiringkan 90 derajat. Susunan monitor tersebut dapat dilihat pada Gambar 4.

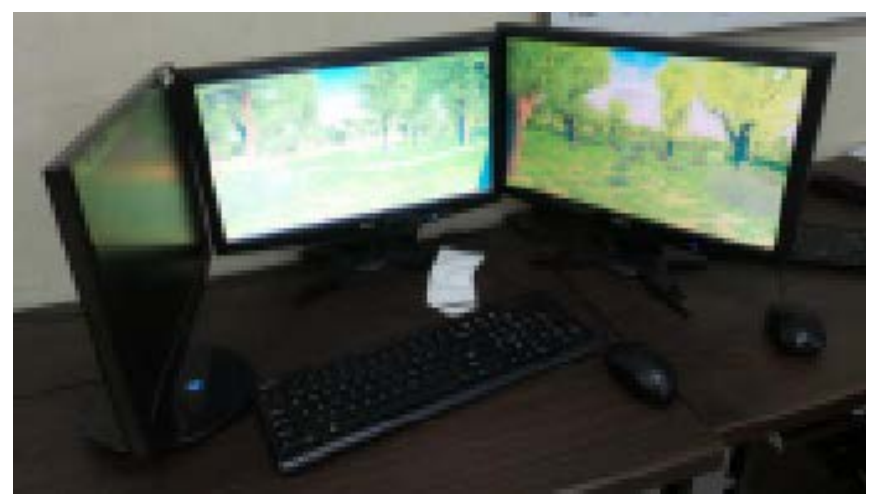

Gambar 4. Monitor yang disusun menyerupai perangkat CAVE

Komputer server dijalankan terlebih dahulu, dilanjutkan dengan komputer client dijalankan lalu dihubungkan dengan komputer server. Tanda apabila komputer client telah terhubung dengan server adalah ketika posisi kamera pada komputer client sama dengan komputer server.

Perangkat ini dilengkapi dengan joypad untuk menggerakkan kamera. Rotasi kamera diatur oleh gyrosensor yang ada pada ponsel. Pengguna dapat mempercepat pergerakan kamera dengan menekan salah satu tombol pada joypad.

\section{UJI COBA}

Uji coba dilakukan dengan mengetes perangkat ini secara langsung kepada pengguna. Pengguna diminta untuk melakukan eksplorasi, dilakukan dengan berinteraksi dengan aplikasi menggunakan joypad dan ponsel yang disediakan, pada dua scene yang telah disediakan. Setelah itu pengguna diberi kuesioner untuk menilai perangkat ini. Aspek yang dinilai adalah tingkat imersif yang dimiliki perangkat ini, tingkat realisme scene yang telah disediakan, dan tingkat rasa pusing yang dialami saat menggunakan perangkat ini.

Penilaian mengenai tingkat imersif yang disajikan oleh perangkat ini dapat dilihat pada Gambar 5.

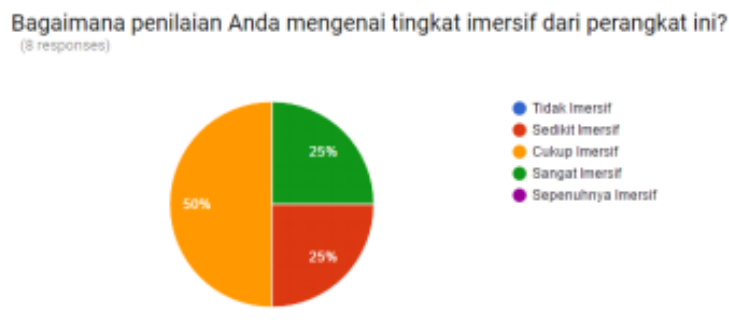

Gambar 5. Grafik penilaian tingkat imersif

Gambar 5 menunjukkan bahwa perangkat masih belum cukup baik dalam menghadirkan imersi kepada pengguna. Hal ini dikarenakan ketika menggunakan monitor, pengguna sulit menangkap pengalaman berada di lingkungan maya yang telah dihadirkan oleh aplikasi. Namun apabila perangkat dapat diterapkan dengan menggunakan komponen yang sesuai, perangkat ini masih memiliki potensi untuk dapat menghadirkan pengalaman imersi yang lebih baik.

Penilaian tingkat realisme dari kedua scene yang telah disediakan dapat dilihat pada Gambar 6 dan Gambar 7.

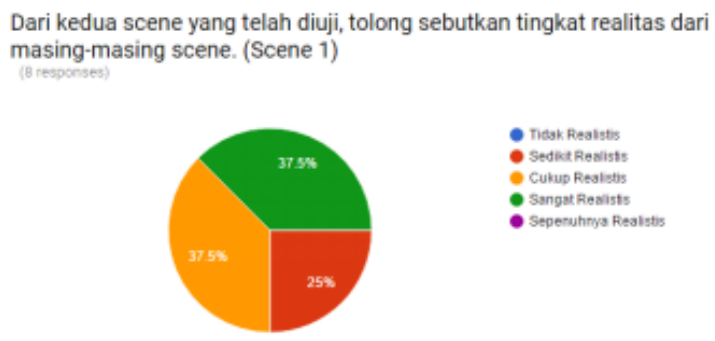

Gambar 6. Grafik penilaian tingkat realisme scene pertama

Dari Gambar 6 dan Gambar 7 dapat dilihat bahwa scene kedua sedikit lebih baik dari scene pertama. Hal ini disebabkan pada scene kedua, objek yang menyusun scene tersebut lebih bervariasi dibandingkan dengan scene pertama. Scene pertama 
Dari kedua scene yang telah diuji, tolong sebutkan tingkat realitas dari masing-masing scene. (Scene 2)
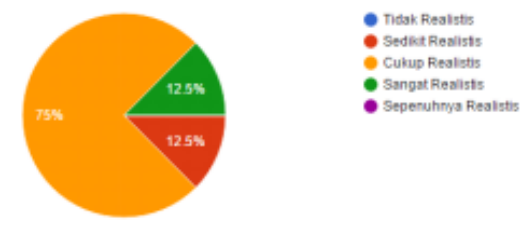

Gambar 7. Grafik penilaian tingkat realisme scene kedua

hanya terdiri dari pepohonan yang memiliki variasi yang sedikit disusun di tempat yang berbeda. Hasil uji coba scene ini menunjukkan hasil yang cukup baik. Akan tetapi sebetulnya scene ini masih dapat jauh ditingkatkan kembali dengan menggunakan objek berdefinisi tinggi.

Selanjutnya mengenai penilaian tingkat rasa pusing yang dialami pengguna dapat dilihat pada Gambar 8.

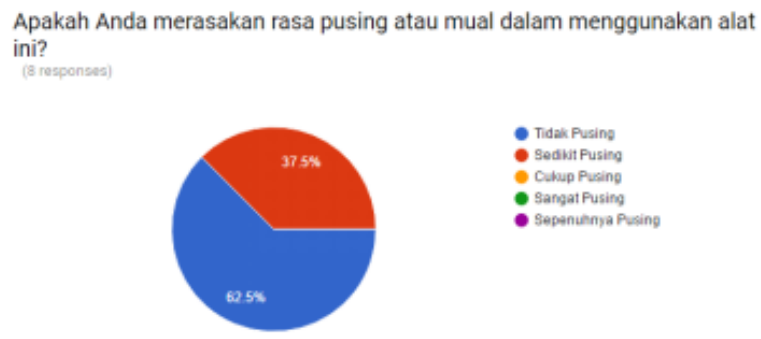

Gambar 8. Grafik penilaian tingkat rasa pusing yang dialami

Secara keseluruhan pengguna tidak merasakan rasa pusing yang berarti pada saat menggunakan perangkat ini. Hal ini ditunjukkan dengan melihat Gambar 8 bahwa sebagian besar responden tidak merasakan rasa pusing saat menggunakan perangkat ini. Penilaian ini menunjukkan hasil yang baik karena pengguna dapat dengan nyaman menggunakan perangkat ini kapanpun. Sering dijumpai pada perangkat realitas maya HMD bahwa pengguna merasa pusing. Rasa pusing ini biasanya timbul akibat adanya ketimpangan antara dunia maya dan dunia nyata. Pada perangkat HMD, pengguna secara keseluruhan terisolasi dari dunia nyata. Hal ini yang menyebabkan rasa pusing itu timbul bagi pengguna. Perangkat ini tidak mengisolasi secara keseluruhan antara dunia maya dan dunia nyata sehingga pengguna tidak merasa pusing saat menggunakan perangkat ini.

\section{KESIMPULAN/RINGKASAN}

Dalam proses pengerjaan Studi ini, mulai dari tahap analisis, desain, implementasi, hingga pengujian didapatkan kesimpulan sebagai berikut:

1. Pengujian fitur menunjukkan bahwa aplikasi telah berhasil dalam menerapkan fitur-fitur penting yang harus dimiliki oleh perangkat ini, akan tetapi beberapa penyesuaian masih dapat dilakukan untuk meningkatkan realisme.

2. Hasil uji coba mengindikasikan bahwa tingkat realisme yang dihadirkan oleh perangkat ini masih kurang memuaskan. Perlunya perangkat yang sesuai bagi perangkat ini sangat memengaruhi tingkat realisme.

3. Scene yang disediakan untuk uji coba aplikasi sudah menghadirkan pengalaman realisme yang cukup baik. Scene ini juga masih dapat ditingkatkan kualitasnya dengan menggunakan aset yang berdefinisi tinggi untuk menghadirkan tingkat realisme yang lebih nyata.

4. Pengguna tidak merasakan rasa pusing ketika menggunakan perangkat ini.

\section{DAFTAR PUSTAKA}

[1] CAVE Automatic Virtual Environment. (n.d.). Diakses tanggal 25 Mei 2016, dari http://www.visbox.com/products/cave/

[2] CAVE Fully Immersive Virtual Reality - Virtual Reality. (n.d.). Diakses tanggal $25 \quad$ Mei 2016, dari http://www.vrs.org.uk/virtual-reality-environments/cave.html

[3] Helgaeson, David. Another Million Unity Developers in the House. July 9, 2013. Diakses tanggal 21 Desember 2016, dari https://blogs.unity3d.com/2013/07/09/another-million-unity-developersin-the-house/

[4] Muhanna, M. A. (18 Maret 2014). Virtual reality and the CAVE: Taxonomy, interaction challenges and research directions

[5] Game developers, start your Unity 3D engines (interview). 2 November 2012. Diakses tanggal 3 Juni 2016, dari http://venturebeat.com/2012/11/02/game-developers-start-your-unity-3d -engines-interview/

[6] Chung, Lawrence. (n.d.). Client-Server Architecture

[7] Unity officially releases its new game engine: Unity 5. 3 Maret 2015. Diakses tanggal 3 Juni 2015, dari http://www.theverge.com/2015/3/3/8142099/unity-5-engine-release 